This item was submitted to Loughborough's Research Repository by the author.

Items in Figshare are protected by copyright, with all rights reserved, unless otherwise indicated.

\title{
The subversive potential of Leo Tolstoy's 'defamiliarisation': a case study in drawing on the imagination to denounce violence
}

PLEASE CITE THE PUBLISHED VERSION

https://doi.org/10.1080/13698230.2019.1565700

\section{PUBLISHER}

(C) Taylor \& Francis (Routledge)

\section{VERSION}

AM (Accepted Manuscript)

\section{PUBLISHER STATEMENT}

This is an Accepted Manuscript of an article published by Taylor \& Francis in Critical Review of International Social and Political Philosophy on 11 January 2019, available online:

http://www.tandfonline.com/10.1080/13698230.2019.1565700.

\section{LICENCE}

CC BY-NC-ND 4.0

\section{REPOSITORY RECORD}

Christoyannopoulos, Alexandre. 2019. “The Subversive Potential of Leo Tolstoy's 'defamiliarisation': A Case Study in Drawing on the Imagination to Denounce Violence". figshare. https://hdl.handle.net/2134/25365. 


\title{
The Subversive Potential of Leo Tolstoy's 'Defamiliarisation': A Case Study in Drawing on the Imagination to Denounce Violence
}

\begin{abstract}
In his later years, Leo Tolstoy wrote numerous books, essays and pamphlets expounding his newly-articulated denunciations of all political violence, whether by dissidents or ostensibly legitimate states. If these writings have inspired many later pacifists and anarchists, it is partly thanks to his masterful deployment of the literary technique of 'defamiliarisation' - or looking at the familiar as if new - to shake readers into recognising the absurdity of common justifications of violence, admitting their implicit complicity in it, and noticing the process which numbed them into accepting such complicity. This paper discusses Tolstoy's use of the imagination to defamiliarise and denounce violence, first by citing a number of typical examples, then by reflecting on four of its subversive characteristics: its disruption of automated perception, its implicit concession of some recognition, its corrosion of conventional respect for traditional hierarchies, and its encouragement of empathy.
\end{abstract}

Keywords: anarchism; defamiliarisation; pacifism; Tolstoy; violence.

\section{Introduction}

Leo Tolstoy (1828-1910) is mainly remembered as the author of two of the world's most praised novels: War and Peace (1869) and Anna Karenina (1877). Less frequently recalled nowadays is that when he passed away, a few years before the First World War and the Bolshevik Revolution, he was just as famous for what might be described as his controversial Christian anarcho-pacifist views. Both then and since, numerous writers, scholars, politicians, religious figures and public intellectuals have engaged and often disagreed with various aspects of his political thought. A mark of the peculiarity of Tolstoy's views is that despite the clear Christian and anarchist themes, both his Christian and his anarchist credentials have been disputed (for instance: Maude, 1930, Spence, 1967, Greenwood, 1978, Wilson, 1988, Matual, 1992, Préposiet, 2005, Kolstø, 2006, Schmidt and van der Walt, 2009). The levelheadedness of his pacifism has also often been questioned, though here the main focus of criticism has been not so much on his denunciations of violence as on his stubbornly puritanical stance (for instance: Kennan, 1887, Maude, 1930, Spence, 1963, Tolstoy, 2001b). Nevertheless, Tolstoy’s pacifist writings have also inspired many, including of course Gandhi, who notoriously in turn inspired countless pacifist activists and thinkers (Tolstoy, 1937b, Lavrin, 1960). Tolstoy stirred many a conscientious objector of his own, and encouraged many to adopt a pacifist stance even if the stance adopted was not always as absolute as Tolstoy's (Fueloep-Miller, 1960, Denner, 2010, Alston, 2014). Controversial though he certainly was, Tolstoy therefore sits as a central figure at the origins of modern pacifism - an ardent ally to those looking to denounce violence (Brock, 1972, Atack, 2012).

One of the reasons Tolstoy proved controversial was his style: his allegedly simplistic arguments, his reductive syllogisms, his seemingly childish naivety (Lenin, 1908, 
Abraham, 1929, Maude, 1930, Berdyaev, 1948, Greenwood, 1978, Seeley, 1978, Wilson, 1988). Yet that style was always also in part what made him so appealing to his supporters: Tolstoy deliberately wanted his readers to cut through the deceitful fog of misleading complications and distractions, and the simplistic purity of his arguments is partly what makes them sharp, accessible and potent. There is a candid and attractive innocence both in the substance of his claims and in the style with which he puts them across.

A particular rhetorical device which generates this impression of naivety, and which Tolstoy used frequently, is what Viktor Shklovsky (in a seminal text for Russian Formalism) called ostranenie (остранение) (Shklovsky, 2006). The term has been translated as 'making strange', 'estrangement', and 'defamiliarisation'. Tolstoy, Shklovsky shows, likes to get his readers to look at the familiar as if seen for the first time, in a childlike manner. He does so by pointedly not calling what he is describing by its accepted name, instead describing it by its component parts, and ignoring the wider context which to most observers gives it its normal meaning and coherence (paraphrasing Knapp, 2002, p. 163, Buchanan, 2010, s.v. “ostranenie”). This allows Tolstoy to describe social, political, religious and other phenomena with the innocence of a child not familiar enough with all the conventions the implicit acceptance of which adults automatically bring to their observation of the phenomenon. It disrupts conventional understandings, hence is potentially subversive. Knapp agrees: 'ostranenie is an effective instrument of social critique' (2002, p. 163). Tolstoy's use of it when articulating his radical views contributed to making them controversial.

The aim of this article is to illustrate and reflect on Tolstoy's use of defamiliarisation in his Christian anarcho-pacifist writings, in particular as a tool to both question the conventions that authorise violence and spark a pacifist critique. What the article will not provide is a critical discussion of these views - such discussions can be found elsewhere (Wilson, 1988, Guseinov, 1999, McKeogh, 2009, Bartlett, 2010). After a brief first section offering some quick remarks on Tolstoy's anarcho-pacifism, the second section of this article illustrates Tolstoy's use of defamiliarisation for subversive purposes, in particular to denounce violence. The third reflects on what makes defamiliarisation potent and subversive. Ultimately, what this article intends to demonstrate is that Tolstoy provides a model in applying defamiliarisation to violence which has not only unsurprisingly lit a pacifist spark in many in the past, but which has not lost much of its potency and relevance today, and which can inspire others to creatively denounce violence and domination in their own evolving context in the unfolding future.

\section{Tolstoy's Christian anarcho-pacifist turn}

The direction of Tolstoy's life changed around 1879, when after a decade-long and increasingly turbulent existential crisis he 'converted' to Christianity, or rather to a peculiar and rationalistic understanding of Christianity based on which he preached a form of anarcho-pacifism. It is conventional for biographers to reject the idea that there are two Tolstoys, one before his conversion and one after (Eikhenbaum, 1967, Gustafson, 1986, Wilson, 1988, Orwin, 2002, Medzhibovskaya, 2008). They rightly point out the numerous continuities between the two periods. It is also the case that 
the separation of Tolstoy into the writer of brilliant fiction (to be read assiduously) and the social critic (wacky, dangerous and best ignored) is one sponsored by the Bolsheviks, for clear political reasons - and the Soviet authorities made sure this approach was enforced as the accepted one across the Soviet bloc (Lenin, 1908, Struve, 1960, Avrich, 1968, Denner, 2010). But Tolstoy (1987) himself did insist on the biographical break. Moreover, his writings after 1879 do clearly have a different purpose - an engaged and primarily political and religious one. Despite the clear continuities, therefore, and without discounting their importance, one can nonetheless approach his 'fame' (Stepun, 1960, p. 157) and his corpus as twofold: what he wrote up to his 'conversion', and what he wrote in light of it thereafter (fiction and nonfiction included). When he died in 1910, he had certainly become notorious both in Russia and abroad for both his fiction and his political and religious views. The main focus of this article is on the latter.

Here is not the place to expand in great depth on Tolstoy's Christian anarchopacifism. What is worth noting by way of a summary is that Tolstoy did not start believing in the resurrection, the miracles, the sacraments or many of the church's dogmas. What he converted to wholesale is the ethics preached by Jesus and its implied analysis of violence, in particular the Sermon on the Mount and Jesus' counsels on turning the other cheek, and more generally Jesus' teachings on (and prefiguration of) love and forgiveness. Based on this new moral outlook, Tolstoy would spend the rest of his life bitterly denouncing the violence human beings inflict on each other: he would denounce the state for exacting violence on an industrial scale without any more legitimacy than a protection racket; he would denounce contemporary violent revolutionaries for foolishly using fire to try to put out fire; and he would denounce the church for burying Jesus' important and radically pacifist ethics under thick layers of superstitions and stupefaction in exchange for stateprotected comfort (Christoyannopoulos, 2008, Christoyannopoulos, 2016). These themes will be evident in the examples of defamiliarisation given below.

Tolstoy's ideas survived him despite the Great War, the Bolshevik revolution, and the persecution of his followers in that tumultuous context. He was read across the world. His Christian anarcho-pacifist writings famously moved Gandhi (with whom Tolstoy had the time to exchange brief letters), but also influenced Romain Rolland, Ludwig Wittgenstein, and many others (Rolland, 1978, Love, 2008, McKeogh, 2009, Alston, 2014). Tolstoy's pacifist writings enraged many, but they inspired many too. They certainly provoked thought and discussion, and this, in no small part due to the brilliance of his defamiliarisation of violence.

\section{Defamiliarising violence}

Tolstoy is not the only writer to master the technique of making the familiar strange. Nonetheless, when Shklovsky coined the term to describe his preferred purpose for art, Tolstoy was the author he chose to rely on to illustrate it - indeed he cited him at length, and then only briefly mentioned a few other authors in what reads almost as an afterthought. This may not be surprising: when Shklovsky wrote and published his essay (in 1916-1917), Russia was unstable, at war, and pregnant with revolutionary spirit. This was also a time when Tolstoy's political corpus was widely read and 
discussed: as Denner puts it, 'For the radicalized intelligentsia of pre-Revolutionary Russia - a description that suits Shklovsky - Tolstoy was something of a patron saint.' (2008, p. 373) Shklovsky had also just been reading Tolstoy's extensive diaries when he was writing his essay. Either way, Tolstoy is the main author Shklovsky cites in his seminal text.

Shklovsky's concern is to portray art as a tool with which to break 'the automatism of perception' (2006, p. 779). He argues that we all naturally settle into 'unconsciously automatic' interpretations of what we observe, that 'perception becomes habitual'. Shklovsky cites holding a pen and speaking a foreign language as examples of automation, but then broadens his argument to suggest that this process of 'habitualization' applies to all aspects of life (2006, p. 778). For Shklovsky, then, as Denner puts it, 'art's purpose, its task, is to cure our diseased knowledge of the world' (2008, p. 376). In Shklovsky's words, its aim 'is to impart the sensation of things as they are perceived and not as they are known' (2006, p. 778). Art should make us approach the familiar without 'the automatism of perception'.

As Denner observes, such an understanding of art is in fact quite similar to Tolstoy's in What Is Art? (1897) (Tolstoy, 1904, Denner, 2008) Besides, one of Tolstoy's recurring themes in his later writings is indeed that people have become hypnotised by habit and deceit into not seeing acts of violence and oppression for what they are. Tolstoy wanted, through his writings, to shake the public out of this hypnotised state, and he saw the purpose of art as to contribute to that.

It is not the intention of this article to comment on whether the whole purpose of art is to be defined as narrowly as something that must always make the familiar strange. Instead, what this article does seek to illustrate is that defamiliarisation is a potent tool in disrupting the narratives of the violent political status quo, a technique therefore worth analysing and deploying in denouncing violence and oppression. Let us now therefore consider some examples.

The very first example Shklovsky gives of Tolstoy using this technique in his essay is a description of flogging - a punishment then recently reintroduced in Tsarist Russia. As quoted by Shklovsky, Tolstoy describes it as:

'to strip people who have broken the law, to hurl them to the floor, and to rap on their bottoms with switches', and, after a few lines, 'to lash about on the naked buttocks'. Then [Tolstoy] remarks: 'Just why precisely this stupid, savage means of causing pain and not any other - why not prick the shoulders or any part of the body with needles, squeeze the hands or the feet in a vise, or anything like that?' (Tolstoy, 1896, Shklovsky, 2006, p. 779)

Shklovsky comments that, here, 'The familiar act of flogging is made unfamiliar both by the description and by the proposal to change its form without changing its nature.' (2006, p. 779) Tolstoy invites us to look at the act through the eyes of a child, even, as Denner comments, 'using words drawn from the readers' memories of their punishment as children' (2008, p. 381). According to Shklovsky, this example 'is typical of Tolstoy's way of pricking the conscience' by 'not naming the familiar' and thus making it 'seem strange', by describing it 'as if he were seeing it for the first time’ (2006, p. 779). 
Shklovsky immediately follows this example with another much more extensive quote where Tolstoy defamiliarises this time the notion of private property by seeing it through the eyes of a horse (Tolstoy, 1886, Shklovsky, 2006, pp. 779-780). Shklovsky then gives several more examples, and notes that hundreds of further examples can be found in Tolstoy's work.

One of the more notorious passages of Tolstoy doing this is with his lengthy depiction of Sunday mass in prison in Resurrection (1899), which includes a classic defamiliarisation of the Eucharist (1966, p. 181). The two full chapters were compressed by the Russian censor to no more than three words: 'The service began.' (Edmonds, 1966, p. 13) The book also sealed Tolstoy's excommunication. Church authorities thus certainly did perceive Tolstoy's defamiliarised accounts as subverting orthodox rituals and beliefs by representing them out of context, as if through the eyes of a seemingly inadvertently insolent child. According to Fernandez, it is indeed perhaps 'especially to criticise religion and priestly hypocrisy' that defamiliarisation has been 'most formidable' (Fernandez, 2010, p. 67 [my translation]). But Tolstoy also targeted other established institutions which he saw as complicit in violence.

Chapter 30 in Resurrection (1966, pp. 148-150) scans the prisoners of a cell, and describes the reason they found themselves imprisoned, in a way that clearly intends to implicitly question the justice of the criminal system. Similar presentations of convicts appear later in the book (1966, p. 235). Throughout the novel, defamiliarisations of various aspects of the judicial system contribute to a relentless ridiculing of it, whilst the nonetheless severe implications in terms of institutional violence are laid bare too. McLean comments that

One of the most searing representations of senseless cruelty in the penal system is the picture of the departure for Siberia of a large group of prisoners. On a day of intense summer heat the victims are lined up in the sun, counted, counted again, and finally marched through the streets of Moscow to the railway station. Several prisoners die of sunstroke or heat exhaustion; all suffer. It is one of those instances, as Nekhliudov analyzes the causes, where it is impossible to pin responsibility for the misery. Every official is just doing his job, following orders; but the result is suffering and death. Official, legal duties make people impervious to the human law written by God in their heart, just as pavement makes a road impervious to rain. (2002, p. 108)

Earlier in the novel, in an illustrative passage too long to cite in full here, Tolstoy introduces an 'aged general' who had received an 'extremely flattering Cross in the Caucasus because under his command close-cropped Russian peasants dressed in uniforms and armed with guns and bayonets had killed more than a thousand men who were defending their liberty, their homes and their families' (1966, pp. 344-345). Throughout Resurrection, Tolstoy thus paints defamiliarised pictures of prisoners and prison officers in a manner which clearly means to trigger reflection about both the absurdity and the violence of the justice system. Law courts are not spared, and also get what McLean calls 'a savagely critical representation' where 'the courtroom and its regalia [are presented] through the naive eyes of Nekhliudov, who is seeing these for the first time' (2002, p. 103). Tolstoy's 'picture of upper-class life' in it is also 'unrelentingly critical', as McLean goes on to explain (2002, p. 106). 
There are many examples of the same technique applied in other late Tolstoyan writings, in particular to depict the horrifying absurdity of violence. In The Kingdom of God Is within You (1893), the text most frequently cited as the main and fullest exposition of his Christian anarchist thinking, Tolstoy describes the demands of the state like this:

Take a man of our time - be he who he may - [...] living quietly when suddenly people come to him and say: 'First you must promise and swear to us that you will slavishly obey us in everything we prescribe to you, and obey and unquestioningly accept as absolute truth everything we devise, decide on, and call law. Secondly you must hand over to us part of the fruits of your labour (we shall use the money to keep you in slavery and to prevent you forcibly resisting our arrangements). Thirdly you must elect others, or be yourself elected, to take a pretended part in the government, knowing all the while that the administration will proceed quite independently of the foolish speeches you and others like you may utter, and that things will proceed according to our will - the will of those in whose hands is the army. Fourthly you must at the appointed time come to the law-courts and take part in the senseless cruelties we perpetrate on erring people whom we have perverted - in the shape of imprisonments, banishments, solitary confinements, and executions. And fifthly and finally, besides all this, although you may be on the friendliest terms with men of other nations, you must be ready, as soon as we order it, to consider as your enemies those whom we shall point out to you, and co-operate, personally or by hiring others, in the destruction, plunder, and murder of their men, women, children and aged alike - perhaps also of your own fellow countrymen or even your parents, should we require that.' (2001b, pp. 238-239)

Painted this way, these central functions of the state obviously look rather unattractive. This particular portrayal is in fact quoted in a classic compilation of Tolstoy's writings on anarchism and nonviolence as evidence of his anarchism (Stephens, 1990, p. 13). Yet this is but one example among many of similar defamiliarisation of state functions which Tolstoy uses to denounce state violence.

Tolstoy's denunciations of state violence are not limited to domestic affairs. In 'Christianity and Patriotism' (1894), Tolstoy looks ahead to the next war he expects Russia to inevitably find itself engaged in:

And hundreds of thousands of simple kindly folk, torn from their wives, mothers, and children, and with murderous weapons in their hands, will trudge wherever they may be driven, stifling the despair in their souls by songs, debauchery, and vodka. They will march, freeze, suffer from hunger, and fall ill. Some will die of disease, and some will at last come to the place where men will kill them by the thousand. And they, too, without themselves knowing why, will murder thousands of others whom they had never before seen, and who had neither done nor could do them any wrong (2001a, p. 449).

Similarly ten years later, as the Russo-Japanese war was breaking out, Tolstoy depicts the collective endeavour to kill with classic defamiliarisation in 'Bethink Yourselves!' (1937a, pp. 212-213) in the hope it might jolt some compatriots out of their hypnotic contribution to the war effort - a hypnotic condition for which Tolstoy frequently laid particular blame on patriotism and on the church. 
In The Kingdom of God Is within You, Tolstoy reflects on how state violence is made possible by the way it is organised: the act is subdivided into several separate tasks, each performed by different persons, all of whom feel the responsibility for the act rests somewhere else, not on them (2001b, pp. 342-368). Tolstoy here anticipates Arendt's famous arguments about the banality of evil (2006), whereby state atrocities are not necessarily caused by atrocious people but merely by human beings each playing their professional role and administering their local task with proud efficiency. That is, according to Tolstoy, hypnotised by conventional political and religious rationalisations and intoxicated by the self-importance of their routinised duties, human beings will collectively commit violence many of them deep down know they should be more questioning of.

There are many more examples of defamiliarisation in Tolstoy's writings. What the limited sample mentioned above hopes to demonstrate is that, whether or not we agree with Tolstoy's broader views on the state or on religion, and even whether or not we still think that some violence is unfortunately sometimes necessary for peace, for order or for some other important cause, the defamiliarisation of organised violence provides a potent device to trigger reflection on exactly what is implicitly authorised by members of the body politic when endorsing mainstream positions and arguments which routinise the infliction of violence.

\section{Defamiliarisation's subversive potential}

What makes Tolstoyan defamiliarisation potentially subversive? In what manner does defamiliarisation affect those exposed to it such that they might reconsider their assumptions? My heuristic suggestion is that defamiliarisation is effective due to at least four reasons: it disrupts routine thinking and briefly opens a moment for reflection; it helps establish some implicit agreement on what is being observed through the complicit bond that underlies the sharing of humour, irony or ridicule; it relativises constructed hierarchies and strips them of their self-importance; and it generates empathy by gazing at the familiar through the eyes of someone else.

\section{Disrupting routine thinking}

Firstly, reading a defamiliarised description of a familiar phenomenon disrupts our automated perception of it. It reminds us of how we may well have approached the phenomenon for the first time as a child, and how much we have become accustomed to the conventional perception, labelling and rationalising of it. The curious description, avoiding the accepted name and describing it with candid sharpness, strikes the reader as refreshingly unusual, and invites pause and reflection. Put back in the mind of a child gazing at it for the first time, one may well in turn be reminded of the questions a child would then ask about why this has to be how it is.

It might be worth remarking in passing that Tolstoy was fond of what he saw as the pure-hearted innocence with which children encounter the world (for instance: Tolstoy, 1910). This is just one of several Rousseauian themes in Tolstoy (Rousseau is probably the thinker that influenced Tolstoy the most: Knapp, 2002, Hamburg, 
2010, Paperno, 2010), and this also influenced the way Tolstoy interpreted Jesus' sayings on children (Tolstoy, 1933, Tolstoy, 1934). That is, Tolstoy took Jesus as sharing his view about children being as yet still untainted by the depraved morality of adults, and by the numbed conscience which will soon enough corrupt them too. Tolstoy wanted to reawaken that uncorrupted conscience in his readers.

Disrupting routine perception was of course precisely one of the purposes which Shklovsky saw in defamiliarisation. As explained above, he argued that 'perception becomes habitual' and 'automatic', and that defamiliarisation is precisely a technique which helps break that (2006, p. 778). It shakes us out of hypnotic, 'anaesthetising' habit, to quote Denner (2008, p. 380). Moreover, as De Goede explains (citing Michel Foucault), 'denaturalizing, or making strange, political practices that appear as natural or common sense' is where the 'practice of criticism' indeed 'begins' (de Goede, 2005, p. 381 (my emphasis)). If one therefore wishes to draw attention to an injustice caused by conventional approaches to a problem, such disruption is an effective first step, a way of provoking reflection. Tolstoy was actually explicitly hoping that his writings would jolt his readers into revisiting conventional perceptions of political violence, that these readers might 'bethink' themselves out of the hypnotised mindset upon which countless arguments that led to violence and injustice were blindly legitimised (Tolstoy, 1902, Tolstoy, 1933, Tolstoy, 1934, Tolstoy, 1937a, Tolstoy, 1937c, Tolstoy, 1948, Tolstoy, 2001b, Tolstoy, 2001c, Tolstoï, n.d.).

There is of course no guarantee that defamiliarisation will disrupt routine perception. There is therefore also no guarantee that jolting readers with anarcho-pacifist defamiliarisations of violence will lead them to anarcho-pacifism. Readers who are moved might eventually settle for liberal arguments for example, or for cold but perhaps more conscious realpolitik. Much like comedy (Brassett, 2016), although defamiliarisation destabilises, the political and ideological end-result is unpredictable. Tolstoy hoped, of course, that his writings might help generate some kind of pacifist momentum. Either way, to the extent that it has the potential to jolt readers into asking why they have labelled and perhaps legitimised something which as a child they would have probably perceived differently, defamiliarisation is a subversive device.

\section{Conceding implicit agreement}

Secondly, what defamiliarisation also tends to do is implicitly concede some recognition of a particular reality. That is, at least if written well, a defamiliarised account will not be queried about the seemingly factual and frank validity of what it describes. What might be disputed is whether that description covers all that one needs to consider before passing final judgement (hence the description could be slated as too naive because omitting some broader aspects which a more mature analysis needs to consider), but the description itself will be accepted as true enough. In other words, critical readers may immediately think beyond what is described and consider explanations that ultimately legitimise what has been described here rather innocently, but they will probably still implicitly agree with the description acknowledging thereby the often ignored or relativised violence of the situation. 
Moreover, the touch of humour, irony, or satire inherent in the presentation of a defamiliarised account contributes to this securing of some recognition. The alreadyconverted will be entertained, but the as-yet-unconverted may be jolted by their laughter because, when one is at least a little amused by a particular defamiliarised portrayal, that amusement typically rests on the validity of that perspective being implicitly recognised. Critchley writes: 'Humour both reveals the situation, and indicates how that situation might be changed' (2002, p. 16). Humour helps a perspective get recognised. Take for example any of the more politically subversive stand-up comedians and entertainers (such as Bill Hicks, Mark Steel, Frankie Boyle or John Oliver), the humorous interventions of some anti-establishment dissenters (such as the Discordians, the Yes Men or the Clown Army), or the political comments in popular American cartoons (such as The Simpsons, South Park or Team America): when you laugh at their depiction of a particular issue, are you not also implicitly recognising a particular 'truth' about it without which the portrayal would not be amusing? That is not to say that what is affirmed with a touch of humour necessarily induces critical reflection or sympathy with a progressive agenda - humour can after all be aggressive, absurd, discriminatory and so on. Humour facilitates a convergence of opinion, but there is no guarantee that this will be a convergence on a progressive or critical viewpoint.

Nevertheless, part of what makes defamiliarisation subversive is this potential to invite implicit recognition of an otherwise routinised and overlooked injustice through humour. The moment one chuckles, one has in effect expressed some agreement about the injustice of what has been described. For instance, if one is at least tickled by the satirical description of flogging relayed above, is one not also implicitly recognising that it is in hindsight quite random and farcical an invented yet also cruel punishment? If one feels drawn to the sarcastic tone with which preparations for war are mentioned above, is one not also thereby by implication acknowledging the scale of the collective effort, the impressively widespread dedication to it by the full breadth of society, and the potency (yet also the questionability) of the ideological spell which legitimises the whole endeavour? By joining Tolstoy in the sarcasm, one is arguably also implicitly converging towards his perspective.

This again does not guarantee eventual agreement with the defamiliariser's ultimate conclusions. Even if one might implicitly concede some recognition for the perspective being portrayed sarcastically, one might still move to cite 'good reasons' to nevertheless still tolerate what is being criticised. But when the recognition that has been implicitly secured concerns otherwise robotically tolerated acts of institutional violence, then even merely getting an acknowledgement of that raw violence can be subversive. Defamiliarisation thereby helps break the spell of the typical spin, doublespeak or propaganda which usually downplays uncomfortable aspects by exposing and focusing one's gaze on what should be uncomfortable clearly and bluntly.

\section{Deriding hierarchies}

Thirdly, Tolstoy's defamiliarisations also erode the respect and the deference which by convention adults are expected to show for political and religious hierarchies. As discussed above, this applies as much to the church as to state institutions like courts 
and the army. By describing the administrative performances, which constitute them, out of their context and through the eyes of a child, these hierarchies look like any other performance - playground games for adults, except of course that the reader knows (and sometimes is pointedly made aware of) the serious and real consequences for human victims. Moreover, Tolstoy's reader gets the impression that anyone could be there, performing this or that solemn role high up a hierarchy. Tolstoy's accounts suggest the people up there are no better than us. The sense of special duty and highbrow professionalism conventionally associated with these roles no longer look as convincing. This was Tolstoy's intention: he wanted to query the reverence people are expected to show for institutions that administer violence, he wanted to encourage empathy for the victims, and he knew his depictions could have that effect.

To anyone ascribing significant value to such hierarchies, Tolstoy's defamiliarised depictions are indeed profane. Defamiliarisation is irreverent because it refuses to respect the depicted institution's pomp and ceremony (it even insolently refuses to call it by its accepted name and title), yet what makes it particularly potent is that it does not simply preach at the reader, but instead presents the observation as seemingly innocent and naive, and in that sense as a perspective the reader can relate to and be amused by. Given the seriousness with which the public is expected to approach the mission of political and religious hierarchies, the cynical absence of deference in defamiliarisation is subversive.

The humorous undertones in Tolstoyan defamiliarisation further contribute to this irreverence. There are parallels here with the similarly subversive potential of other forms of humour. Brassett discusses the extent to which the British comedy of Russell Brand, Charlie Brooker and Stewart Lee acts as a form of resistance to the 'dominant forms of market subjectivity' produced by the global political economy (2016, p. 168). De Goede argues that carnival and laughter in dissent and resistance against the global financial industry can actually contribute to challenging its power (2005). Odysseos shows how Aristophanic comedy amounted to an acerbic critique of Athens' religious and political orthodoxies (2001). To these examples can now be added Tolstoyan defamiliarisation, even though it essentially consists of one particular kind of satire (the candid irony of an innocent child) and has here been discussed primarily for one particular kind of resistance (an anarcho-pacifist critique violence).

\section{Facilitating empathy}

Fourthly and finally, defamiliarisation is powerful for yet another reason: it facilitates empathy. For one, Brassett argues (following Rorty) that irony 'can foster a greater sensitivity to the suffering of others by recognising [...] the practical effects of seeing more and more people as fellow sufferers' (2009, p. 221). Moreover, Tolstoy saw one of the purposes of art as to transmit the feelings that one has experienced, in other words to encourage empathy in the reader for the feelings one is expressing (Tolstoy, 1904, Emerson, 2002). To look at a phenomenon as if for the first time is to try to approach it unconstrained by the emotional attachments and allegiances which had come to automatically derive from one's actual position in the canvas of society. It means both that familiar affections are suspended and that affections for people hitherto disregarded might be discovered. In other words, new patterns of empathy 
might emerge. Tolstoy's defamiliarised accounts of violence are quite deliberately crafted to incite the reader to feel the injustice, the absurdity, and the suffering caused. One is made to feel for the victims, and one is left pondering how one would react if inflicted the same treatment.

Tolstoy saw the core ethical teaching of all religious traditions as essentially a variation on the Golden Rule, the ethical guideline which calls us to do unto others as we would prefer be done to us (Christoyannopoulos, 2014). This Golden Rule is premised on a reciprocal treatment of each other as equals. By relativising constructed hierarchies and by framing our gaze as that of an innocent child, Tolstoy's defamiliarised accounts flatten our differences and in effect encourage ethical reflection potentially framed through the Golden Rule. To be clear: defamiliarisation on its own does not guarantee that behaviour will be changed to the kind of empathetic reciprocity embedded in the Golden Rule, but it acts as an invitation in that direction.

To encourage empathy is to potentially subvert legitimisations of violence because few are those who like to be at the receiving end of violence. Empathy challenges attempts to dehumanise those portrayed as enemies. Once their humanity is reinstated, the suffering inflicted by violence cannot be ignored. If the arguments that are supposed to justify violence against enemies then turn out to be comparable to those which the humans on the other side are meant to subscribe to in order to be violent themselves, then the absurdity of both sides' violence is all the more exposed. Both dehumanisation and defamiliarisation modify perception, but in opposing directions: Tolstoyan defamiliarisation tends to 'rehumanise' by reawakening a purer gaze untainted by conventional hierarchies and moulded identities, a gaze more open to empathy. It is more difficult to inflict violence when one feels empathy for the victim, and therefore to the extent that defamiliarisation promotes empathy, it undermines the agenda of the advocates of such violence.

\section{Concluding reflections}

Defamiliarisation is not new, nor was Tolstoy the only one to use it. My contention, to sum up, is that Tolstoy, who is the main example repeatedly cited by Shklovsky in the text that coined the term for this artistic technique, is also a writer whose defamiliarised depictions of violence are still compelling and potentially subversive, and provide an example that might inspire others to develop the same technique. One need not agree with Tolstoy on the radical anarchism or his proposed solutions in order to still share indignation about the violence he is drawing attention to, and feel moved to do something about it. Defamiliarised descriptions of the violence that humans inflict on each other are moving: they disrupt routine perceptions, concede some recognition of systemic violence, relativise hierarchies and encourage empathy.

Unlike Shklovsky, I am not claiming defamiliarisation is 'the purpose of art' (2006, pp. 778, emphasis added), nor do I wish to limit its use to those who define themselves as artists, but what I am endorsing is the claim that it is a potent tool in raising public awareness - be that of injustices, the raw reality of violence, the role of institutions in administering those, or any other automated social practice. It is 
because of this subversive potential that twentieth-century artistic movements such as Dada and intellectual perspectives such as poststructuralism have advocated and used similar techniques, and more recent counter-cultural activities such as culturejamming, subvertising, and satirical news production have been employing it too. The wider public also seems to enjoy taking part in defamiliarisation when posting and reposting memes and news commentaries that seek to provoke reflection through it.

Furthermore, defamiliarisation is only one of a broader range of aesthetic devices and practices which suspend or disrupt reality in different ways. From Bakhtin's 'carnival time' to Art Spiegman's Maus, from anti-capitalist street theatre to Banksy, there are many ways to try to turn the world upside down, to disrupt the unthinking and automatised reproduction of modes of behaviour and frames of thought which we all readily settle into as we busily navigate the social landscape that surrounds us. There is never any guarantee that any such attempts to disrupt routine will work, let alone that any even successful unsettling will ultimately lead to the new perspectives and practices sought by those who seek change. But sometimes, they do. There is no guarantee that reading Tolstoy will disrupt one's tacit acceptance of the mechanised administration and legitimisation of violence and open space for potential critical reflection, but for some readers, it has done.

Admittedly, such causal influences can be difficult to establish unequivocally: they involve shifts in perception in the minds of audiences and readers, which are difficult to measure; there may also often be other contextual factors that are contributing to a shift in opinion; and sometimes the seeds of a new perception might have been growing in one's mind for a while already anyway. Nonetheless, one type of source of evidence of shifts in perception includes the biographies, confessions and autobiographies of those who revised their views after what they describe as a disruptive jolt. Alston for instance cites many a Tolstoyan convert of this kind, ranging from lawyers and judges who abruptly walked away from their stable profession after having read Tolstoy, experienced soldiers who felt moved enough to wholly adopt and advocate Tolstoyan pacifism, and of course Gandhi who credits Tolstoy for impressing upon him the importance of a firm moral commitment to nonviolence (Jahanbegloo, 1998, Alston, 2010). Tolstoy gained a sufficient-enough following to worry public authorities and move them to censor his writings and repress his disciples. Defamiliarisation is not the only ingredient that makes Tolstoyan pacifism a subversive concoction, but it does contribute to its particular flavour.

Today, the same aesthetic ingredient can help raise awareness of more contemporary types of political violence, including, for instance: the violence caused by borders and routinised discourses and procedures concerning international migration; the violent enforcement of economic inequalities; or the violence sold by a military-industrial complex and the trading of weapons for profit. Indeed perhaps defamiliarised accounts of global production processes might help unmask some of the connections and indirect culpabilities tied to the consumption of products stained by violence, from raw material extraction which funds civil wars to brutal employment practices and habitat destruction. More generally, defamiliarisation can help disrupt the often rather quick and unquestioning endorsement of routinised violence and war as a means to an end - whether domestically in dominant regimes of disciplining and punishment, or internationally when evoking Just War arguments for instance as facile 
excuses for war-making. Artistic disruptions of routinised violence thus add a dimension to the literature that seeks to think about credible and more peaceful alternatives to the violent human practices which enforce today's global geopolitical economy.

Tolstoy hoped to reach many different kinds of readers - the Russian intelligentsia, socialists, Christians, the aristocracy, the literary public, etc. - each with different roles and kinds of complicity in the systemic violence he denounced. Today's global society is even more complex, and the type and degree of complicity of the different cogs of the current system considerably more complicated too. Globalised neoliberal capitalism, policed by the Westphalian order, is effective at hiding its production processes from consumers, hiding the effect of pension funds and private savings on the victims of their investments, hiding the front-line from the distant clerk, hiding the impact of economic austerity from the busy middle classes. If anything, this makes even more apposite and urgent the deployment of techniques of defamiliarisation to help expose the complex causality underlying today's systemic violence.

Deep down, most citizens know there are deep injustices in the world, most do not like violence inflicted on them, and most realise much violence is inflicted out there because of the various accepted realities of the twenty-first century world. Yet the acceptance of this reality rests on automated perceptions and arguments which, when queried through the eyes of an innocent child, can be harder to justify. That child-like naivety poses a challenge to those complicit in perpetrating or accepting the perpetration of violence. To those who have assimilated the conventional justifications of violence, a dose of defamiliarisation can disrupt and invite critical reflection. To a humanity still contaminated by violence and injustice, perhaps one could do worse than advise the reading of some of the later writings of the celebrated author of War and Peace.

\section{References}

Abraham, J.H., 1929. The religious ideas and social philosophy of Tolstoy. International Journal of Ethics, 40 (1), 105-120.

Alston, C., 2010. Tolstoy's guiding light [online]. History Today. Available from: http://historytoday.com/charlotte-alston/tolstoys-guiding-light [Accessed Access Date 2010].

Alston, C., 2014. Tolstoy and his disciples: The history of a radical international movement London: I. B. Tauris.

Arendt, H., 2006. Eichmann in Jerusalem London: Penguin.

Atack, I., 2012. Nonviolence in political theory Edinburgh: Edinburgh University Press.

Avrich, P., 1968. Russian anarchists and the civil war. Russian Review, 27 (3), 296306.

Bartlett, R., 2010. Tolstoy: A Russian life London: Profile.

Berdyaev, N., 1948. The voice of conscience from another world: An introduction. Essays from tula. London: Sheppard, 9-18. 
Brassett, J., 2009. British irony, global justice: A pragmatic reading of Chris Brown, Banksy and Ricky Gervais. Review of International Studies, 35 (1), 219-245.

Brassett, J., 2016. British comedy, global resistance: Russell Brand, Charlie Brooker and Stewart Lee. European Journal of International Relations, 22 (1), 168191.

Brock, P., 1972. Pacifism in europe to 1914 Princeton: Princeton University Press.

Buchanan, I., 2010. A dictionary of critical theory [online]. Oxford University Press. Available from:

http://www.oxfordreference.com/view/10.1093/acref/9780199532919.001.000 1/acref-9780199532919-e-501 [Accessed Access Date 2016].

Christoyannopoulos, A., 2008. Leo Tolstoy on the state: A detailed picture of Tolstoy's denunciation of state violence and deception. Anarchist Studies, 16 (1), 20-47.

Christoyannopoulos, A., 2014. The golden rule on the green stick: Leo Tolstoy's international thought for a 'postsecular' age. In Mavelli, L. \& Petito, F. eds. Towards a postsecular international politics: New forms of community, identity, and power. London: Palgrave Macmillan, 81-102.

Christoyannopoulos, A., 2016. Leo Tolstoy's anticlericalism and its contemporary extensions: A case against churches and clerics, religious and secular. Religions, 7 (5), 59.

Critchley, S., 2002. On humour London: Routledge.

De Goede, M., 2005. Carnival of money: Politics of dissent in an era of globalizing finance. In Amoore, L. ed. The global resistance reader. London: Routledge, 379-391.

Denner, M.A., 2008. Dusting off the couch (and discovering the Tolstoy connection in Shklovsky's "art as device"). The Slavic and Eastern European Journal, 52 (3), 370-388.

Denner, M.A., 2010. The 'proletarian lord': Leo Tolstoy's image during the Russian revolutionary period. In Orwin, D.T. ed. Anniversary essays on tolstoy. Cambridge: Cambridge University Press, 219-244.

Edmonds, R., 1966. Introduction. Resurrection. London: Penguin, 5-16.

Eikhenbaum, B.M., 1967. On Tolstoy's crises. In Matlaw, R.E. ed. Tolstoy: A collection of critical essays. Englewood Cliffs: Prentice-Hall, 52-55.

Emerson, C., 2002. Tolstoy's aesthetics. In Orwin, D.T. ed. The Cambridge companion to Tolstoy. Cambridge: Cambridge University Press, 237-251.

Fernandez, D. 2010. Subrepticement subversif. Le Magazine Littéraire, November. Fueloep-Miller, R., 1960. Tolstoy the apostolic crusader. Russian Review, 19 (2), 99121.

Greenwood, E.B., 1978. Tolstoy and religion. In Jones, M. ed. New essays on tolstoy. Cambridge: Cambridge University Press, 149-174.

Guseinov, A.A., 1999. Faith, God, and nonviolence in the teachings of Lev Tolstoy. Russian Studies in Philosophy, 38 (2), 89-103.

Gustafson, R.F., 1986. Leo Tolstoy: Resident and stranger: A study in fiction and theology Princeton: Princeton University Press.

Hamburg, G.M., 2010. Tolstoy's spirituality. In Orwin, D.T. ed. Anniversary essays on Tolstoy. Cambridge: Cambridge University Press, 138-158.

Jahanbegloo, R., 1998. Gandhi: Aux sources de la non-violence Paris: Félin.

Kennan, G., 1887. A visit to count Tolstoi. The Century Magazine, 34 (2), 252-265. 
Knapp, L., 2002. The development of style and theme in Tolstoy. In Orwin, D.T. ed. The Cambridge companion to Tolstoy. Cambridge: Cambridge University Press, 161-175.

Kolstø, P., 2006. The demonized double: The image of Lev Tolstoi in Russian orthodox polemics. Slavic Review, 65 (2), 304-324.

Lavrin, J., 1960. Tolstoy and Gandhi. Russian Review, 19 (2), 132-139.

Lenin, V.I., 1908. Leo Tolstoy and the mirror of the Russian revolution [online]. Marxist Internet Archive. Available from: http://www.marxists.org/archive/lenin/works/1908/sep/11.htm [Accessed Access Date 2011].

Love, J., 2008. Tolstoy: A guide for the perplexed London: Continuum.

Matual, D., 1992. Tolstoy's translation of the gospels: A critical study Lewiston: Edwin Mellen.

Maude, A., 1930. The life of Tolstóy: Later years London: Oxford University Press.

Mckeogh, C., 2009. Tolstoy's pacifism Amherst, New York: Cambria.

Mclean, H., 2002. Resurrection. In Orwin, D.T. ed. The Cambridge companion to Tolstoy. Cambridge: Cambridge University Press, 96-110.

Medzhibovskaya, I., 2008. Tolstoy and the religious culture of his time: A biography of a long conversion, 1845-1887 Lanham, MD: Lexington.

Odysseos, L., 2001. Laughing matters: Peace, democracy and the challenge of the comic narrative. Millennium: Journal of International Studies, 30 (3), 709732.

Orwin, D.T., 2002. Introduction: Tolstoy as artist and public figure. In Orwin, D.T. ed. The Cambridge companion to Tolstoy. Cambridge: Cambridge University Press, 49-62.

Paperno, I., 2010. Leo Tolstoy's correspondence with Nikolai Strakhov: The dialogue on faith. In Orwin, D.T. ed. Anniversary essays on Tolstoy. Cambridge: Cambridge University Press, 96-119.

Préposiet, J., 2005. Histoire de l'anarchisme, Reviewed and expanded ed. Paris: Pluriel.

Rolland, R., 1978. Vie de Tolstoï Paris: Albin Michel.

Schmidt, M. \& Van Der Walt, L., 2009. Black flame: The revolutionary class politics of anarchism and syndicalism Oakland: AK.

Seeley, F.F., 1978. Tolstoy's philosophy of history. In Jones, M. ed. New essays on Tolstoy. Cambridge: Cambridge University Press, 175-193.

Shklovsky, V., 2006. Art as technique. In Richter, D.H. ed. The critical tradition: Classic texts and contemporary trends. Third ed. Boston: Bedford/St.Martin's, 774-784.

Spence, G.W., 1963. Suicide and sacrifice in Tolstoy's ethics. Russian Review, 22 (2), 157-167.

Spence, G.W., 1967. Tolstoy the ascetic. Edinburgh: Oliver and Boyd.

Stephens, D., 1990. The non-violent anarchism of Leo Tolstoy. In Stephens, D. ed. Government is violence: Essays on anarchism and pacifism. London: Phoenix, 7-19.

Stepun, F., 1960. The religious tragedy of Tolstoy. Russian Review, 19 (2), 157-170.

Struve, G., 1960. Tolstoy in soviet criticism. Russian Review, 19 (2), 171-186.

Tolstoï, L.N., n.d. What to do? London: Walter Scott. 
Tolstoy, L., 1886. Kholstomeer: The story of a horse [online]. The Long Riders Guild Academic Foundation. Available from: http://www.lrgaf.org/training/kholstomer.htm [Accessed Access Date 2016].

Tolstoy, L., 1896. Shame! [online]. www.nonresistance.org. Available from: http://www.nonresistance.org/docs_htm/Tolstoy/Shame.html [Accessed Access Date 2016].

Tolstoy, L., 1902. What I believe <my religion> London: C. W. Daniel.

Tolstoy, L., 1904. What is art? New York: Funk \& Wagnalls Company.

Tolstoy, L., 1910. The wisdom of children [online]. www.nonresistance.org. Available from:

http://www.nonresistance.org/docs_htm/Tolstoy/Wisdom_of_Children.html [Accessed Access Date 2016].

Tolstoy, L., 1933. The gospel in brief. A confession and the gospel in brief. London: Oxford University Press, 113-302.

Tolstoy, L., 1934. The teaching of Jesus. On life and essays on religion. London: Oxford University Press, 346-409.

Tolstoy, L., 1937a. Bethink yourselves! Recollections and essays. London: Oxford University Press, 204-271.

Tolstoy, L., 1937b. Gandhi letters. Recollections and essays. London: Oxford University Press, 433-439.

Tolstoy, L., 1937c. Thou shalt not kill. Recollections and essays. London: Oxford University Press, 195-203.

Tolstoy, L., 1948. The slavery of our times. Essays from Tula. London: Sheppard, 65136.

Tolstoy, L., 1966. Resurrection London: Penguin.

Tolstoy, L., 1987. A confession. A confession and other religious writings. London: Penguin, 17-80.

Tolstoy, L., 2001a. Christianity and patriotism. The kingdom of God and peace essays. New Delhi: Rupa, 422-500.

Tolstoy, L., 2001b. The kingdom of God is within you: Christianity not as a mystical doctrine but as new understanding of life. The kingdom of God and peace essays. New Delhi: Rupa, 1-421.

Tolstoy, L., 2001c. Patriotism and government. The kingdom of God and peace essays. New Delhi: Rupa, 501-529.

Wilson, A.N., 1988. Tolstoy: A biography New York: Norton. 